\title{
Prevalence of genital Chlamydia trachomatis infection in the general population of Slovenia: serious gaps in control
}

\author{
I Klavs, L C Rodrigues, K Wellings, D Keše, R Hayes
}

Sex Transm Infect 2004;80:121-123. doi: 10.1136/sti.2003.005900

Objectives: One of the objectives of the first national survey of sexual lifestyles, attitudes, and health in Slovenia was to estimate the prevalence of and risk factors for genital Chlamydia trachomatis infection in Slovenian adults aged 18-49 years.

Methods: Data were collected over 1999-2001 from a probability sample of the general population by face to face interviews and anonymous self administered questionnaires. Respondents were invited to provide a first void urine (FVU) specimen for polymerase chain reaction testing for $C$ trachomatis infection. We compared the results to the equivalent British survey.

Results: 1447 individuals contributed FVU specimens (82.6\% of survey respondents, $55.3 \%$ of those eligible). C trachomatis infection was diagnosed in $3.0 \%$ of men and $1.6 \%$ of women. Prevalence was highest in men and women aged $18-24$ years $(4.1 \%$ for both). Individuals reporting first heterosexual intercourse before the age of 16 , unprotected sexual intercourse with at least one heterosexual partner during the preceding year, concurrent heterosexual relationships during the preceding year, and five or more lifetime heterosexual partners had a higher prevalence. The association was statistically significant only for five or more lifetime partners (adjusted OR 3.0; $95 \% \mathrm{Cl} 1.3$ to 6.9; $p=0.01)$.

Conclusions: A relatively high prevalence of genital $C$ trachomatis infection among 18-24 year old Slovenians, in the presence of relatively low risk sexual behaviour and low reported incidence rates of chlamydia infection, suggest serious gaps in the diagnosis and treatment of the condition. The results provide support for the introduction of chlamydia screening in Slovenia.

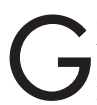
enital Chlamydia trachomatis infection is presumed to be the most common curable sexually transmitted infection in Slovenia. Studies of convenience samples in Slovenian healthcare settings reported prevalences from $6 \%$ to $16.5 \%$ among asymptomatic women and from $2.7 \%$ to $3.2 \%$ among asymptomatic men. ${ }^{1-4}$ Although these estimates are subject to selection bias, they suggest that the low reported incidence rate ( 12 per 100000 population in 2002) based on mandatory notification of diagnosed cases substantially underestimates the true burden. The low reported incidence may also result from the low estimated rate of testing for $C$ trachomatis $(217$ tests in public health laboratories per 100000 population in 2002). One of the objectives of the first National Survey of Sexual Lifestyles, Attitudes and Health in Slovenia was to estimate the prevalence of genital $C$ trachomatis infection and identify demographic and behavioural determinants.

\section{METHODS}

We used stratified two stage probability sampling of the general population 18-49 years old. Data were collected between November 1999 and February 2001 at respondents' homes by a combination of face to face interviews and anonymous self administered pencil and paper questionnaires adapted from the British National Survey of Sexual Attitudes and Lifestyles conducted in 1990.5 Respondents were invited to provide a urine specimen for testing for genital $C$ trachomatis infection. Following signed informed consent, participants provided approximately $10 \mathrm{ml}$ of first void urine (FVU) in a plastic, sterile container. Specimens were frozen and stored at $-20^{\circ} \mathrm{C}$ at interviewers' homes on the day of collection and transported to the laboratory in cold boxes every 2 weeks. The Amplicor PCR test (Roche Diagnostic) for $C$ trachomatis was performed on pool sizes of five thawed specimens. ${ }^{67}$ Internal controls to identify inhibitory specimens were used. ${ }^{8}$ Specimens from reactive pools were retested individually. Cases of $C$ trachomatis infection were referred for treatment. The linkage of testing results with the information reported by respondents is described elsewhere. ${ }^{9}$

Weights were computed to adjust for differences between the sample and Slovenian population estimates according to sex, age, region, and size and type of community. Statistical methods for complex survey data (Stata statistical software, Release 7.0) were used to account for stratification, two stage sampling, and weighting. Univariate and multivariate analyses of association between $C$ trachomatis infection and explanatory variables were performed by logistic regression. $C$ trachomatis prevalence and selected indicators of high risk sexual behaviour in sexually experienced individuals aged 18-24 years were compared to the results from the British National Survey of Sexual Attitudes and Lifestyles conducted during the same period..$^{10}{ }^{11}$

Ethical approval was obtained from the medical ethics committees of the Ministry of Health of the Republic of Slovenia and the London School of Hygiene and Tropical Medicine.

\section{RESULTS}

In all, 849 men and 903 women aged 18-49 years were interviewed. Survey response was $67.0 \%, 63.3 \%$ among men and $70.9 \%$ among women. A total of 683 men and 764 women, $82.6 \%$ of survey respondents, were tested for $C$ trachomatis infection. Taking into account survey nonresponse, the participation rate in FVU specimen collection among eligible individuals was 55.3\%, 50.9\% among men and $60.0 \%$ among women.

Genital $C$ trachomatis infection prevalence rates in men and women by age are shown in table 1 . Age specific prevalence was highest among 18-24 year olds, $4.1 \%$ (95\% CI 2.2 to 7.4 ) in both men and women. Excluding individuals who had never had sexual intercourse (vaginal, oral, or anal), the prevalence was $4.7 \%$ (CI 2.5 to 8.5 ) in both men and women. 


\begin{tabular}{|c|c|c|c|c|c|c|}
\hline \multirow{4}{*}{$\begin{array}{l}\text { Table } 1 \\
\text { by age }\end{array}$} & \multicolumn{6}{|c|}{ Prevalence of genital $C$ trachomatis infection among Slovenian men and women } \\
\hline & \multicolumn{3}{|c|}{ Men } & \multicolumn{3}{|c|}{ Women } \\
\hline & \multicolumn{3}{|c|}{ Prevalence } & \multicolumn{3}{|c|}{ Prevalence } \\
\hline & $\%$ & $\begin{array}{l}\text { (p value*) } \\
95 \% \mathrm{Cl}\end{array}$ & $\begin{array}{l}\text { Bases } \\
\text { UWT, WT }\end{array}$ & $\%$ & $\begin{array}{l}\text { (p value*) } \\
95 \% \mathrm{Cl}\end{array}$ & $\begin{array}{l}\text { Bases } \\
\text { UWT, WT }\end{array}$ \\
\hline Age & & $(0.42)$ & & & $(<0.01)$ & \\
\hline $18-24$ & 4.1 & 2.2 to 7.4 & 252,160 & 4.1 & 2.2 to 7.4 & 265,153 \\
\hline $25-34$ & 3.6 & 1.6 to 7.7 & 166,218 & 2.0 & 0.7 to 5.1 & 199,216 \\
\hline $35-49$ & 2.1 & 0.9 to 4.9 & 265,352 & 0.3 & 0.0 to 2.0 & 300,348 \\
\hline All ages & 3.0 & 1.9 to 4.6 & 683,730 & 1.6 & 1.0 to 2.7 & 764,718 \\
\hline
\end{tabular}

Prevalences and odds ratios for $C$ trachomatis infection among 18-24 year old individuals, according to selected sexual behaviours, are shown in table 2. Prevalence was higher in those reporting first heterosexual intercourse before the age of 16, unprotected sexual intercourse with at least one heterosexual partner during the preceding year, concurrent heterosexual relationships during the preceding year, and five or more lifetime heterosexual partners. However, the association was statistically significant only for five or more lifetime partners (age and sex adjusted OR 3.0; CI 1.3 to 6.9; $\mathrm{p}=0.01)$.

Sexually experienced Slovenians aged 18-24 years have lower risk reported sexual behaviour than the corresponding groups in Britain: mean annual sexual partner acquisition rates among Slovenian men and women were 1.1 (SD 3.6) and 0.4 (SD 0.9) and among British 1.7 (SD 3.5) and 0.8 (SD 1.7). Proportions of those with at least five lifetime heterosexual partners among Slovenian men and women were $36.9 \%$ (CI 31.6 to 42.4 ) and $17.7 \%$ (CI 13.8 to 22.4 ), and among British $48.0 \%$ (CI 44.1 to 51.8 ) and $43.6 \%$ (CI 40.2 to 47.0). Finally, proportions of those with concurrent sexual relationships during the preceding year among Slovenian men and women were $13.3 \%$ (CI 9.4 to 18.5 ) and $8.1 \%$ (CI 5.2 to 12.2 ) and among British $22.6 \%$ (CI 19.2 to 26.5 ) and $16.1 \%$ (CI 13.4 to 19.4 ).

\section{DISCUSSION}

The prevalence of $C$ trachomatis infection among sexually experienced Slovenians aged $18-24$ is substantial, at $4.7 \%$ (CI 2.5 to 8.5$)$ in both sexes. The corresponding estimates for Britain are appreciably lower, $2.7 \%$ (CI 1.2 to 5.8 ) among men and $3.0 \%$ (CI 1.7 to 5.0 ) among women, ${ }^{10}$ in spite of the higher reported prevalence of risk behaviours in Britain. However, confidence intervals for these prevalence estimates were wide and the differences between countries were not statistically significant. In Slovenia, methods for the transport, storage, and laboratory testing of FVU were robust, whereas the British researchers indicated that they may have underestimated the prevalence. ${ }^{10}$ Neither this, nor participation biases can be excluded as accounting for part of the observed difference in prevalence.

Slovenian men and women aged 18-24 reported lower risk sexual behaviour than their British counterparts. There is no evidence that Slovenians are more likely to under-report high risk sexual behaviour than the British, in spite of differences in the cultural context and slight differences in survey methodology. This cannot however be excluded as accounting for part of the apparent differences in behaviour. Improved reporting accuracy was assumed for some sensitive behaviours in the 2000 British survey, compared with the 1999 survey, in line with greater social tolerance and improved methodology. ${ }^{12}$

Why is the estimated prevalence of genital $C$ trachomatis infection among 18-24 year old Slovenians higher than among the British, if there is lower risk sexual behaviour in Slovenia? Together with low $C$ trachomatis testing rates and low reported infection rates, our results suggest serious gaps in the diagnosis and treatment of $C$ trachomatis infection in Slovenia. This implies that a large proportion of infections remain untreated, and provides strong support for the introduction of $C$ trachomatis infection screening.

Table 2 Association of genital $C$ trachomatis infection with selected sexual behaviour characteristics among Slovenians aged 18-24 years

\begin{tabular}{|c|c|c|c|c|c|c|}
\hline Behaviour & $\begin{array}{l}\text { CT prevalence* \% } \\
(95 \% \text { CI) }\end{array}$ & $\begin{array}{l}\text { Bases } \\
\text { UWT, WT }\end{array}$ & OR & $\begin{array}{l}\text { (p value) } \\
95 \% \mathrm{Cl}\end{array}$ & $\begin{array}{l}\text { Adjustedt } \\
\text { OR }\end{array}$ & $\begin{array}{l}\text { (p value) } \\
95 \% \mathrm{Cl}\end{array}$ \\
\hline \multicolumn{7}{|c|}{ Early FHI (before age 16) } \\
\hline No & $3.6(2.1$ to 6.2$)$ & 436,263 & 1 & (0.28) & 1 & $(0.69)$ \\
\hline Yes & $6.4(2.7$ to 14.4$)$ & 81,50 & 1.8 & 0.6 to 5.3 & 1.3 & 0.4 to 4.0 \\
\hline \multicolumn{7}{|c|}{$1+$ heterosexual partner without $100 \%$ condom use, past year $\$$} \\
\hline No & $2.7(0.7$ to 10.1$)$ & 77,48 & 1 & (0.27) & 1 & (0.43) \\
\hline Yes & $5.9(3.7$ to 9.5$)$ & 321,193 & 2.3 & 0.5 to 10.5 & 1.9 & 0.4 to 10.1 \\
\hline \multicolumn{7}{|c|}{ Concurrency past year } \\
\hline No & $3.8(2.3$ to 6.3$)$ & 467,282 & 1 & (0.28) & 1 & (0.84) \\
\hline Yes & 7.5 (2.4 to 21.3$)$ & 40,25 & 2.0 & 0.6 to 7.5 & 1.2 & 0.3 to 5.1 \\
\hline \multicolumn{7}{|c|}{$5+$ lifetime heterosexual partners } \\
\hline No & $2.8(1.5$ to 5.0$)$ & 374,225 & 1 & $(0.01)$ & 1 & $(0.01)$ \\
\hline Yes & $7.8(4.2$ to 13.9$)$ & 137,84 & 3.0 & 1.3 to 7.0 & 3.0 & 1.3 to 6.9 \\
\hline
\end{tabular}

*Prevalence of genital $C$ trachomatis infection. †Adjusted for 5+ lifetime heterosexual partners, age (18-19, 20-24 years), and sex. \#First heterosexual intercourse. \$Had at least one heterosexual partner with whom condoms were not used on $100 \%$ occasions of heterosexual vaginal and/or anal intercourse. $\mathrm{Cl}=$ confidence interval; UWT = unweighted count; WT = weighted count; OR = odds ratio. 


\section{ACKNOWLEDGEMENTS}

We thank the respondents; the interviewers; contributers to the survey implementation: Marta Arnež, Zdenka Blejec, Marta GrgičVitek, Zdenka Kastelic, Andrej Kveder, Marjan Premik, Igor Švab, Metka Zaletel; and Catherine Mercer for British estimates. The study was supported by grants from the Ministry of Health, Ministry of Science and Technology, City Council of Ljubljana, Health Insurance Institute of Slovenia, Merc \& Dohme Idea Inc., Krka, and Lek. Roche Diagnostics contributed Amplicor Chlamydia trachomatis PCR testing kits.

\section{CONTRIBUTORS}

IK designed the study, coordinated the implementation, analysed, interpreted the data and was the lead writer; LCR, KW, and RH participated in the study design, interpretation of the results and preparation of this paper; DK coordinated the laboratory testing and contributed to this paper.

\section{Authors' affiliations}

I Klavs, AIDS/STD Unit, Communicable Diseases Department, Institute of Public Health of the Republic of Slovenia, Liubljana, Slovenia

L C Rodrigues, R Hayes, Infectious Disease Epidemiology Unit, Department of Infectious and Tropical Diseases, London School of Hygiene and Tropical Medicine, London, UK

K Wellings, Health Promotion Research Unit, Department of Public Health and Policy, London School of Hygiene and Tropical Medicine, London, UK

D Keše, Institute of Microbiology and Immunology, Medical Faculty, University of Liubliana, Slovenia

Sources of support: The study was supported by grants from the Ministry of Health, Ministry of Science and Technology, City Council of Liubliana, Health Insurance Institute of Slovenia, Merc \& Dohme Idea Inc, Krka, and Lek. Roche Diagnostics contributed Amplicor Chlamydia trachomatis PCR testing kits.

Conflict of interest: None.
Correspondence to: Dr Irena Klavs, Institute of Public Health of the Republic of Slovenia, Trubarjeva 2, 1000 Liubliana, Slovenia; Irena.Klavs@ivz-rs.si

Accepted for publication 17 July 2003

\section{REFERENCES}

1 Hren-Venceli H, Kralj B, Derganc M. Kaj vemo o spolno prenesenih klamidijskih okužbah v Sloveniji. Zdrav Vestn 1995;64(Suppl 3):65-7.

2 Kožuh-Novak M, Andolšek L, Kunej-Planinšček Z, et al. Rizični dejavniki pri vnetju rodil. Zdrav Vestn 1988:57:37-40.

3 Avanzo-Velkavrh M, Assejev V, Novak-Antolič Ž. Vnetja v obporodnem obdobju. Zdrav Vestn 1998;67:515-8.

4 Skaza-Maligoi A, Hren-Vencelj H, Štorman A, et al. Prevalence of chlamydial urethritis in males in the Celje region. Alpe Adria Microbiol J 1996;5:243-51.

5 Johnson AM, Wadsworth J, Wellings K, et al. Sexual attitudes and lifestyles. Oxford: Blackwell Scientific, 1994.

6 Peeling RW, Toye B, Jessamine $\mathrm{P}$, et al. Pooling of urine specimens for PCR testing: a cost saving strategy for Chlamydia trachomatis control programmes. Sex Transm Infect 1998;74:66-70

7 Moore SA, Meijer CJ, Munk C, et al. Pooling of urine specimens for detection of asymptomatic Chlamydia trachomatis infections by PCR in a low-prevalence population: cost saving strategy for epidemiological studies and screening programs. J Clin Microbiol 2000;38:1679-80.

8 Chernesky MA, Jang D, Sellors J, et al. Urinary inhibitors of polymerase chain reaction and ligase chain reaction and testing of multiple specimens may contribute to lower assay sensitivities for diagnosing Chlamydia trachomatis infected women. Mol Cell Probes 1997; 11:243-9.

9 Klavs I, Rodrigues LC, Wellings K, et al. Feasibility of testing for Chlamydia trachomatis in a general population sexual behaviour survey in Slovenia. Int J STD AIDS 2002;13(Suppl 2):5-8.

10 Fenton KA, Korovessis C, Johnson AM, et al. Sexual behaviour in Britain: reported sexually transmitted infections and prevalent genital Chlamydia trachomatis infection. Lancet 2001;358:1851-4.

11 Johnson AM, Mercer CH, Erens B, et al. Sexual behaviour in Britain: partnerships, practices, and HIV risk behaviours. Lancet 2001;358:1835-42.

12 Copas AJ, Wellings K, Erens B, et al. The accuracy of reported sensitive sexual behaviour in Britain: exploring the extent of change 1990-2000. Sex Transm Infect 2002;78:26-30. 